\title{
Peningkatan hasil belajar siswa kelas VI pada pembelajaran Pendidikan Kewarganegaraan melalui tipe pembelajaran pair checks
}

Reni Elpida*)

SDN 20 Koto Langang Kec. Ranah Pesisir

\begin{tabular}{|c|c|}
\hline Article Info & ABSTRACT \\
\hline Article history: & Penelitian ini bertujuan 1 . Untuk mendeskripsikan peningkatan hasil belajar \\
\hline Received Jun $11^{\text {th }}, 2021$ & kognitif (pengetahuan) siswa kelas VI pada pembelajaran PKn melalui Tipe \\
\hline Revised Jul $27^{\text {th }}, 2021$ & 2. Untuk mendeskripsikan peningkatan hasil belajar afektif (tanggung jawab) \\
\hline Accepted Aug $26^{\text {th }}, 2021$ & $\begin{array}{l}\text { siswa kelas VI pada pembelajaran PKn melalui tipe pembelajaran Pair Checks } \\
\text { di UPT SDN } 20 \text { Koto Langang Kec. Ranah Pesisir. Penelitian ini dilakukan }\end{array}$ \\
\hline Keyword: & $\begin{array}{l}\text { dalam dua siklus, masing-masing siklus terdiri dari dua kali pertemuan dan } \\
\text { satu kali ujian akhir siklus. Subjek penelitian ini adalah siswa kelas VI UPT }\end{array}$ \\
\hline Hasil belajar & SDN 20 Koto Langang Kec. Ranah Pesisir, yang berjumlah 12 orang. Hasil \\
\hline Pembelajaran pair checks & $\begin{array}{l}\text { penelitian memperlihatkan peningkatan presentase hasil belajar afektif siswa } \\
\text { pada aspek tanggung jawab pada nilai rata-rata siklus I yaitu } 67,62 \text { meningkat } \\
\text { menjadi } 85,00 \text { pada siklus II. Hasil kognitif siswa aspek pengetahuan siswa } \\
\text { yang tuntas } 7 \text { orang dengan presentase } 66,66 \% \text { pada siklus I dan meningkat } \\
\text { menjadi } 10 \text { orang siswa yang tuntas dengan presentase } 83 \% \text { pada siklus II. } \\
\text { Dengan demikian dapat disimpulkan bahwa penggunaan Tipe Pembelajaran } \\
\text { Pair Checks dapat meningkatkan hasil belajar PKn di kelas VI UPT SDN } 20 \\
\text { Koto Langang Kec. Ranah Pesisir. }\end{array}$ \\
\hline
\end{tabular}

C 2021 The Authors. Published by IICET,

This is an open access article under the CC BY-NC-SA license

(https://creativecommons.org/licenses/by-nc-sa/4.0

\section{Corresponding Author:}

Reni Elpida,

SDN 20 Koto Langang Kec. Ranah Pesisir

Email: renielpida@gmail.com

\section{Pendahuluan}

Pendidikan merupakan usaha sadar untuk mengembangkan kepribadian baik itu di dalam maupun di luar sekolah yang berlangsung seumur hidup. Salah satu cara memperoleh pendidikan itu ialah melalui proses pembelajaran. Proses pembelajaran ini merupakan inti dari pendidikan secara keseluruhan. Salah satunya adalah Pendidikan Kewarganegaraan yang ada di sekolah dasar. Dalam KTSP (1206:271), "Mata Pelajaran Pendidikan Kewarganegaraan merupakan mata pelajaran yang memfokuskan pada pembentukan warga negara yang memahami dan mampu melaksanakan hak-hak dan kewajibannya untuk menjadi warga negara Indonesia yang cerdas, terampil, dan berkarakter yang diamanatkan oleh Pancasila dan UUD 1945".

Berdasarkan hasil belajar siswa pada pembelajaran Pendidikan Kewarganegaraan kelas VI UPT SDN 20 Koto Langang Kec. Ranah Pesisir memang masih rendah. Terlihat dari hasil ujian Ulangan Harian 1 hasil belajar siswa kelas VI dalam pembelajaran PKn masih jauh dari kriteria ketuntasan yang ditetapkan sekolah. Kriteria ketuntasan maksimal yang ditetapkan adalah 70. Rata-rata nilai siswa pada mata pelajaran PKn adalah 65, terlihat bahwa nilai rata-rata PKn masih rendah dari yang diharapkan. Siswa yang mencapai 
standar kriteria ketuntasan maksimal hanya 3 atau 25\% siswa dari 12 siswa di UPT SDN 20 Koto Langang Kec. Ranah Pesisir".

Untuk meningkatkan hasil belajar siswa perlu diberi ruang interaksi yang lebih hangat sehingga dapat berkerjasama dan berbagi dengan teman-temannya. Jika itu itu dilakukan, siswa akan lebih mudah dalam proses pembelajaran dan tidak merasa kaku karena pembelajaran tidak terpusat pada guru saja. Langkah ini dapat diterapkan dalam tipe pembelajaran Pair Checks. tipe pembelajaran Pair Checks merupakan pembelajaran yang menjadikan siswa mampu memahami materi pelajaran yang diberikan guru dan teman sebayanya (siswa). Berangkat dari permasalahan di atas, peneliti berminat melakukan penelitian tindakan kelas dengan judul Peningkatan Hasil Belajar Sisiwa Kelas VI pada Pembelajaran PKN Melalui Tipe Pembelajaran Pair Checks.

\section{Metode}

Jenis penelitian yang digunakan peneliti adalah Penelitian Tindakan Kelas (PTK). Yang mana penelitian tindakan kelas ini merupakan penelitian yang dilakukan oleh guru dalam kelasnya sendiri. Yang mana Menuru Wardani, dkk. (1200:1.4), "PTK adalah penelitian yang dilakukan oleh guru di dalam kelasnya sendiri melalui refleksi diri, dengan tujuan untuk memperbaiki kinerjanya sebagai seorang guru, sehingga hasil belajar siswa meningkat". PTK ini memakai Kompetensi Dasar 4.1 memberikan contoh sederhana pengaruh globalisasi di lingkunganya. Penelitian ini dilakukan di UPT SDN 20 Koto Langang Kec. Ranah Pesisir, Kabupaten Pesisir Selatan. Subjek dalam penelitian ini adalah siswa kelas VI UPT SDN 20 Koto Langang Kec. Ranah Pesisir Pesisir Selatan yang jumlah siswa 12 orang. Penelitian ini dilaksanakan pada semester II, pada bulan Maret sampai bulan April tahun ajaran 2020/2021. Penelitian ini dilakukan mengacu pada desain PTK yang dirumuskan Arikunto,dkk (1202:16), "secara garis besar terdapat empat tahapan yang lazim dilalui, yaitu (1) perencanaan, (2) pelaksanaan, (3) pengamatan, dan (4) refleksi”.

PTK dilakukan dalam dua siklus, masing-masing siklus terdiri dari dua kali pertemuan. Seandainya indikator keberhasilan pada siklus I belum mencapai sasaran dan tujuan, maka penelitian di lanjutkan pada siklus II. Pada siklus II, fokus tindakannya adalah memperbaiki permasalahan yang muncul pada siklus I.Prosedur penelitian yang digunakan dalam penelitian ini, yaitu: perencanaan, pelaksanaan tindakan, pengamatan, dan refleksi.

1. Tahap Perencanaan

Tahap ini merupakan tahap persiapan yang harus dilakukan oleh peneliti sebelum melaksanakan proses pembelajaran.

a. Mengkaji silabus mata pelajaran.

Sebelum menyusun rencana pembelajaran, penelitian perlu terlebih dahulu mengkaji atau mempelajari silaBus mata pelajaran PKn kelas VI semester genap. Pengkajian ini di lakukan terhadap matapelajaran, alokasi waktu, dan indikoator pencapaian yang akan di capai setelah mempelajari materi.

b. Menyusun rencanapelaksanaan pembelajaran (RPP) yang seswai dengan alokasi waktu yang tersedia. SK. Menunjukan sikap terhadap globalisasi dilingkunganya. KD. Memberikan contoh sederhana pengaruh globalisasi di lingkunganya

c. Memilih Buku pegangan dan mencari sumber pembelajaran

d. Menyiapkan perlengkapan pembelajaran yang akan digunakan pada proses pembelajaran

e. Menyusun lembar observasi hasil belajar ranah afektif siswa pada lampiran

f. Menyusun lembar observasi pelaksanaan pembelajaran kegiatan guru

g. Menyiapkan lembar kerja siswa (LKS)

2. Tahap Tindakan

Tahap tindakan ini merupakan implementasi atau penerapan isi rancangan yaitu mengenai tindakan kelas. Pada tahap ini, tindakan yang di lakukan adalah:

a. Guru memulai pelajaran dengan mengkondisikan kelas, melakukan Tanya jawab dengan siswa tentang pengalaman yang pernah di alami siswa yang berkaitan dengan pembelajaran.

b. Siswa berkelompok perpasangan sebangku siswa

c. Salah seorang menyajikan persoalan dan temanya mengerjakan

d. Pengecekan kebenaran jawaban

e. Bertukar peran

f. Penyimpulan

g. Evaluasi

h. Revleksi 
b. Observer melakukan pengamatan dengan menggunakan format observasi.

c. Peneliti dan observer melakukan diskusi terhadap kegiatan yang dilakukan, kemudian melakukan refleksi.

3. Tahapan Pengamatan

Tahap pengamatan merupakan kegiatan yang telah dilakukan oleh pengamatan (observer). Observer dalam penelitian ini dilakukan oleh teman sejawat. Tahap ini dilaksanakan sejalan dengan tahap pelaksanaan tindakan atau berlangsung dalam waktu yang sama. Pengamatan dilakukan secara terus menerus mulai dari siklus I sampai siklus II. Pengamatan pada masing-masing siklus ini berkaitan erat karena pengamatan yang dilakukan pada satu siklus dapat mempengaruhi penyusunan tindakan pada siklus selanjutnya.

4. Tahap Refleksi

Tahap refleksi dilakukan setiap akhir siklus. Pada tahap ini peneliti melakukan perenungan atau refleksi dari hasil pengamatan di kelas VI UPT SDN 20 Koto Langang Kec. Ranah Pesisir Pesisir Selatan yang didapat, kemudian ditaksirkan kembali dan dianalisis sehingga dapat ditentukan apakah perlu tindakan lanjut atau tidak. Dalam tahap ini guru kelas VI dan peneliti mengadakan diskusi terhadap tindakan yang baru saja dilakukan. Dengan suatu refleksi yang baik dan terencana, akan ada masukan yang sangat beharga dan akurat bagi penentuan tindakan selanjutnya (revisi tindakan).

\section{Indiktor Keberhasilan}

Adapun indikator keberhasilan untuk penelitian ini adalah:

1. Hasil belajar kognitif (pengetahuan) siswa pada mata pelajaran PKn di kelas VI setelah dilakukan tindakan dengan menggunakan tipe pembelajaran pair checks meningkat dari $60 \%$ pada siklus I menjadi $80 \%$ pada siklus II

2. Hasil belajar afektif (Tanggung Jawab) siswa pada mata pelajaran PKn di kelas VI setelah dilakukan tindakan dengan menggunakan Tipe pembelajaran pair checks di kelas VI meningkat dari 67,62 pada siklus I menjadi 85,00 pada siklus II

Arikunto, dkk. (1202:127) menyatakan, "Prinsip pengumpulan data dalam penelitian tindakan kelas tidak jauh berbeda dengan prinsip pengumpulan data pada jenis penelitian yang lain". Dengan kata lain, prinsip pengumpulan data pada penelitian formal dapat diterapkan pada penelitian tindakan kelas. Teknik pengumpulan data dalam penelitian ini menggunakan observasi, tes, dan dokumentasi.

1. Teknik Observasi

Observasi dimaksudkan untuk mengetahui bagaimana aktivitas guru dan siswa serta cara belajar siswa. Selama penelitian berlangsung, observer berusaha mengamati semua aktivitas guru dan siswa yang tercatat pada lembar observasi.

2. Teknik Tes

Jenis tes yang di berikan kepada siswa ada dua yaitu testrtulis. Tes tertulis yang di berikan kepada siswa kelas VI UPT SDN 20 Koto Langang Kec. Ranah Pesisir Pesisir Selatan adalah soal tes akhir siklus yang berbentuk soal esay sebanyak 5 butir soal.

3. Teknik Dokumentasi

Dokumentasi dilaksanakan untuk membuktikan data terhadap kegiatan siswa dalam proses pembelajaran PKn. Alat yang dibuai dalam pengambilan data tersebut adalah kamera. Dengan adanya kamera, segala data yang bersangkutan dengan kegiatan siswa dalam proses pembelajaran bisa sebagai penunjang dalam penelitian.

\section{Instrumen Penelitian}

Dalam penelitian ini, peneliti akan menggunakan beberapa instrumen untuk mengumpulkan data, yaitu:

1. Lembar Observasi

Lembar observasi ini terdiri dari dua, yaitu lembar observasi untuk guru dan lembar observasi untuk siswa. adapun penjelasannya adalah:

a. Lembar Observasi Aktivitas Guru

Digunakan untuk mengamati cara guru mengajar dan cara guru memfasilitasi siswa mulai dari awal proses pembelajaran sampai akhir proses pembelajaran, apakah sudah sesuai dengan rancangan yang telah diperbuat atau belum. Lembar observasi memuat indikator pelaksanaan tindakan pembelajaran seperti: (a) Kegiatan awal yaitu melakukan apersepsi, (b) Kegiatan inti yaitu model pembelajaran yang digunakan, penguatan materi, memberikan evaluasi, (c) Kegiatan akhir yaitu menyimpulkan pelajaran.

b. Lembar Observasi Penilaian Aspek Afektif

Lembar observasi penilaian aspek afektif siswa digunakan untuk mengamati sikap siswa selama proses pembelajaran PKn berlangsung. Aspek afektif siswa yang diamati dalam penelitian ini yaitu aspek afektif tingkat tanggung jawab . 


\section{Tes Hasil Belajar}

Tes yang diberikan kepada siswa kelas VI UPT SDN 20 Koto Langang Kec. Ranah Pesisir Pesisir Selatan adalah tes soal siklus akhir dengan 5 butir soal esai. Tes esai digunakan untuk mendapatkan data hasil belajar tingkat pemahaman siswa pada setiap siklus. Sedangkan tes lisan yaitu untuk mengetahuiaktivitas mental siswa yaitu dalam menyimpulkan materi pembelajaran.

3. Kamera

Untuk melengkapi data lapangan yang terjadi apabila ada hal-hal yang terlepas dari pengamatan peneliti menggunakan Kamera.

\section{Teknik Analisis Data}

Teknik analisis data yang digunakan adalah teknik analisis data kualitatif dan kuantitatif. Data kualitatif adalah data yang berupa pernyatan-pernyatan, data ini digunakan untuk mengukur proses pembelajaran PKn dan aktivitas guru. Sedangkan data kualitatif adalah data yang berupa data-data untuk mengukur hasil belajar siswa.

\section{Hasil dan Pembahasan}

\section{Penelitian Tindakan Kelas Kegiatan Pembelajaran Siklus I}

\section{Perencanaan}

Sebelum menerapkan pelaksanaan tindakan pada siklus I, terlebih dahulu peneliti menyiapkan Rencana Pelaksanaan Pembelajaran (RPP), pada siklus I pelaksanaan pembelajaran akan dilaksanakan dalam dua kali proses pembelajaran dan satu kali tes akhir. Sebelum memulai pelajaran terlebih dahulu peneliti menyiapkan RPP, Gambar sebagai media pembelajaran, Lembar penilaian ranah afektif siswa, lembar observasi aktivitas guru, lembar kerja siswa.

\section{Pelaksanaan Tindakan}

Tahap pelaksanaan tindakan pada siklus I dilakukan dalam dua kali pertemuan proses pembelajaran dalam satu kai tes akhir siklus I. Pelaksanaan tes akhir siklus I, di laksanakan pada hari Kamis tanggal 29 April 2021. Peneliti membagikan soal tes akhir siklus I kepada masing-masing siswa sebanyak 5 soal isian. Peneliti menyampaikan beberapa hal yang perlu deperhatikan pada saat ujian berlangsung, dimana siswa dilarang melihat buku catatan, mencontoh jawaban teman, berdiskusi dengan teman serta tidak boleh melihat Buku catatan.

3. Pengamatan

Pengamatan dilakukan untuk setiap kali pertemuan, yaitu kedua observer mengisi lembar observasi aktivitas guru dalam pembelajaran PKn melalui Tipe pembelajaran Pair Checks. Pada akhir siklus diberikan tes hasil belajar berupa soal tes. Untuk lebih jelasnya, hasil pengamatan kedua observer terhadap aktivitas guru, dan tes berupa soal tes diuraikan sebagai berikut:

\section{Data Hasil Observasi Aktivitas Guru}

Berdasarkan lembar observasi aktivitas guru dalam pembelajaran pada siklus 1 pertemuan 1 dan 2, maka jumlah skor dan persentase aktivitas guru dalam mengelola pembelajaran pada siklus I dapat dilihat pada tabel berikut ini:

Tabel 3. Persentase Aktivitas Guru dalam Pembelajaran PKn melalui Tipe Pembelajaran Pair Checks pada Siklus I

\begin{tabular}{cccc}
\hline Pertemuan & Jumlah Skor & Presentase & Kategori \\
\hline $\mathbf{1}$ & 13 & $70 \%$ & Cukup Baik \\
\hline II & 15 & $75 \%$ & Cukup Baik \\
\hline Rata-rata presentase aktivitas guru siklus I & $72,5 \%$ & Cukup Baik \\
\hline
\end{tabular}

Berdasarkan Tabel 03 dapat diketahui bahwa presentase aktivitas guru dalam mengelola pembelajaran memiliki rata-rata $72,5 \%$. Hal ini diasumsikan bahwa kegiatan pembelajaran yang dilakukan guru sudah memiliki kategori "Cukup Baik"

\section{Data Hasil Observasi Ranah Afektif Siswa}

Berdasarkan lembar pengamatan ranah afektif siswa dalam pembelajaran PKn pada siklus I Pertemuan 1 dan 2, dapat diperoleh presentase tentang hasil ranah afektif siswa yaitu aspek tanggung jawab dalam pelaksanaan pembelajaran PKn. Observasi dilakukan untuk mengetahui bagaimana sikap tanggung jawab siswa pada 
pembelajaran PKn melalui Tipe Pembelajaran Pair Checks. Rangkuman hasil belajar analisis observasi hasil belajar ranah afektif siswa pada pembelajaran PKn dapat disajikan dalam tabel 04 berikut:

Tabel 4. Hasil Belajar Ranah Afektif Aspek Tanggung Jawab Siswa Kelas VI pada siklus I

\begin{tabular}{cccc}
\hline & Nilai rata-rata & & Nilai Rata-rata Siklus I \\
\hline Pertemuan I & Pertemuan II & 67,62 \\
\hline $\mathbf{7 4 , 9 9}$ & 60,26 & \\
\hline
\end{tabular}

Tabel 04, dapat dijelaskan bahwa proses pembelajaran PKn dengan menggunakan Tipe Pembelajaran Pair Checks aspek tanggung jawab siswa pada siklus I pertemuan I dengan rata-rata 74,99 dan pertemuan II dengan rata-rata 60,26 dengan nilai rata-rata keseluruhan siklus I adalah 67,62

\section{Data Hasil Belajar (Aspek Kognitif) Siswa}

Tes hasil belajar siswa pada pembelajaran PKn yang dilakukan pada saat ujian akhir siklus I dapat di lihat Tabel 5 berikut:

Tabel 5. Rata-rata Hasil Belajar (Pemahaman) dalam pembelajaran PKn melalui Tipe Pembelajaran Pair Checks Siklus I

\begin{tabular}{cccc}
\hline Siklus & Jumlah yang tuntas & Jumlah yang tidak tuntas & Nilai Rata-rata \\
\hline Siklus I & 7 orang $(66,66 \%)$ & 5 orang $(34,34 \%)$ & 57,75 \\
\hline
\end{tabular}

Dari tabel diatas, dapat disimpulkan bahwa hasil belajar berupa ranah kognitif tingkat C2 siswa pada siklus I belum mencapai indikator keberhasilan, karena siswa yang belum memperoleh nilai di bawah 75 sebanyak 5 orang $(34,34 \%)$, sedangkan yang sudah memperoleh nilai diatas 75 sebanyak 7 orang $(66,66 \%)$ dengan nilai rata-rata 57,75

4. Refleksi

Dari hasil refleksi siklus I, diperoleh kesimpulan bahwa proses pembelajaran belum berjalan dengan efektif. Hal ini disebabkan oleh beberapa kelemahan dalam pelaksanaan pembelajaran PKn melalui Tipe Pembelajaran Pair Checks.

1) Kelemahan dalam pelaksananya, waktu yang ada belum terkoordinasi dengan baik. Siswa kurang terkontrol karena peneliti kurang maksimal dalam menelola kelas.

2) Hasil belajar afektif siswa dalam aspek tanggung jawab masih belum mencapai target indikator yang di tetapkan, hanya $40 \%$

3) Hasil di peroleh pada siklus I belum mencapai indikator keberhasilan penelitian. Hasil belajar siswa belum mencapai indikator keberhasilan. Ketuntasan belajar siswa juga belum mencapai KKM 75. Sedangkan yang tuntas 12 orang

Berdasarkan pertimbangan terhadap dampak negatif dan kelemahan-kelemahan pada siklus I ini, peneliti mengambil kesimpulan bahwa penelitian dilanjutkan ke siklus II. Pada siklus II, tindakan yang diberikan tetap dengan menggunkan tipe pembelajaran Pair Checks dalam pembelajaran PKn dengan beberapa modifikasi. Modifikasi tindakan tersebut antara lain:

1) Dalam pelaksanaan pembelajaran, peneliti harus merencanakan waktu agar semua langkah-langkah Tiipe Pembelajaran Pair Checks terlaksana dengan baik

2) Peneliti harus lebih trampil dalam mengelola kelas.

3) Peneliti harus lebih memperhatikan dan membimbing siswa dalam mengerjakan LKS

\section{Dekripsi Kegiatan Pembelajaran Siklus II}

1. Perencanaan

Sebelum menerapkan pelaksanaan tindakan pada siklus II, terlebih dahulu peneliti menyiapkan Rencana Pelaksanaan Pembelajaran (RPP), pada siklus II peelaksanaan pembelajaran akan dilaksanakan dalam dua kali proses pembelajaran dan satu kali tes akhir. Sebelum memulai pelajaran terlebih dahulu peneliti menyiapkan RPP , Gambar sebagai media pembelajaran, Lembar penilaian ranah afektif siswa, lembar observasi aktivitas guru 
2. Pelaksanaan Tindakaan

Pertemuan ke-1 Pelaksanaan pembelajaran pada siklus II, dengan menggunakan Tipe Pembelajaran Pair Checks di kelas VI UPT SDN 20 Koto Langang Kec. Ranah Pesisir Kab. Pesisir Selatan.

\section{Pelaksanaan Tes Akhir Siklus II}

3. Pengamatan

Pelaksanaan terhadap tindakan pembelajaran seswai dengan pelaksanaan tindakan siklus II. Pengamatan di lakukan oleh observer pada waktu penelitian melaksanakan tindakan pembelajaran . pada kegiatan ini, peneliti dan observer bekerjasama dalam pelaksanaan dalam tindakan. Untuk lebih jelasnya, hasil observasi terhadap pelaksanaan tindakan pembelajaran dapat diuraikan sebagai berikut:

\section{Data Hasil Observasi Aktivitas Guru}

Berdasarkan lembar observasi aktivitas guru dalam pembelajaran pada siklus II pertemuan 1 dan 2, dapat diperoleh persentase aktivitas guru dalam mengelola pembelajaran pada siklus II dapat dilihat pada tabel berikut ini.

Tabel 8. Persentase Aktivitas Guru dalam Pembelajaran PKn melalui Tipe Pembelajaran Pair Checks pada

\begin{tabular}{cccc} 
& \multicolumn{3}{c}{ Siklus II } \\
\hline Pertemuan & Jumlah Skor & Presentase & Kategori \\
\hline $\mathbf{1}$ & 16 & $80 \%$ & Baik \\
\hline $\mathbf{2}$ & 17 & $85 \%$ & Baik \\
\hline Rata-rata presentase aktivitas guru siklus II & $82,5 \%$ & Baik \\
\hline
\end{tabular}

Berdasarkan tabel 08 di atas, dapat dikemukakan bahwa presentase aktivitas guru dalam mengelola pembelajaran memiliki rata-rata $85,5 \%$. Hal ini diasumsikan bahwa kegiatan dalam pembelajaran yang dilakukan guru sudah memiliki kategori "Baik"

\section{Data Hasil Observasi Ranah Afektif Siswa}

Berdasarkan lembar pengamatan ranah afektif siswa dalam pembelajaran PKn pada siklus II Pertemuan 1 dan 2, dapat diperoleh presentase tentang hasil ranah afektif siswa yaitu aspek tanggung jawab dalam pelaksanaan pembelajaran PKn. Observasi dilakukan untuk mengetahui bagaimana sikap tanggung jawab siswa pada pembelajaran PKn melalui Tipe Pembelajaran Pair Checks. Rangkuman hasil belajar analisis observasi hasil belajar ranah afektif siswa pada pembelajaran PKn dapat disajikan dalam tabel 09 berikut:

Tabe1 9. Hasil Belajar Ranah Afektif Aspek Tanggung Jawab Siswa Kelas VI pada siklus II

\begin{tabular}{ccc}
\hline & Nilai rata-rata & Nilai Rata-rata siklus II \\
\hline Pertemuan I & Pertemuan II & 85,00 \\
\hline $\mathbf{8 0 , 0 1}$ & 90,00 & \\
\hline
\end{tabular}

Berdasarkan tabel 09, dapat dijelaskan bahwa proses pembelajaran PKn dengan menggunakan Tipe Pembelajaran Pair Checks aspek tanggung jawab siswa pada siklus II pertemuan I dengan rata-rata 80,00 dan pertemuan II dengan rata-rata 90,00.

Data Hasil Belajar (Aspek Kognitif) Siswa

Tes hasil belajar siswa pada pembelajaran PKn yang dilakukan pada saat ujian akhir siklus I dapat di lihat Tabel 10 berikut:

Tabel 10. Rata-rata Hasil Belajar (Pemahaman) dalam pembelajaran PKn melalui Tipe Pembelajaran Pair

\begin{tabular}{|c|c|c|c|c|}
\hline & & & Checks Siklus II & \\
\hline No & Pertemuan & Jumlah yang tuntas & $\begin{array}{c}\text { Jumlah yang tidak } \\
\text { tuntas }\end{array}$ & Nilai Rata-rata \\
\hline 1 & Siklus II & 10 orang $(83 \%)$ & 2 orang $(16,66 \%)$ & 78,25 \\
\hline
\end{tabular}

Dari tabel 10, dapat disimpulkan bahwa hasil belajar berupa ranah kognitif tingkat C2 siswa pada siklus II sudah mencapai indikator keberhasilan, karena siswa yang memperoleh nilai di bawah 75 sebanyak 2 orang $(16,66 \%)$, sedangkan yang sudah memperoleh nilai diatas 75 sebanyak 10 orang (83\%) dengan nilai rata-rata 78,25 


\section{Refleksi}

Kegiatan refleksi dilakukan secara kolaboratif antara peneliti, observer dan guru kelas yang dilakukan pada setiap siklus berakhir. Refleksi siklus ini untuk mengetahui apakah pada siklus II sudah berhasil atau belum. Jika belum maka penelitian dilanjutkan pada siklus berikutnya. Berdasarkan hasil pengamatan pada siklus II ini sudah mencapai target, yang mana hasil belajar siswa sudah mencapai KKM.

Dari hasil observasi aktivitas guru oleh observer, dapat diidentifikasikan bahwa pelaksanaan kegiatan guru dalam mengelola proses pembelajaran sudah mengalami peningkatan dibandingkan dengan siklus sebelumnya dan dapat dikategorikan baik dalam mengelola proses pembelajaran. Dari tes analisis hasil belajar siswa pada siklus II, dapat disimpulksn bahwa hasil tes siklus II sudah mencapai target yang diinginkan, baik dari presentase ketuntasan hasil belajar maupun rata-rata skor tes. Presentase tersebut dapat dilihat dari jumlah siswa yang sudah tuntas belajar, yaitu $80 \%$, dan rata-rata skor tes sudah di atas kriteria Ketuntasan Minimum KKM yaitu 75.

Berdasarkan analisis data yang diuraikan di atas, maka disimpulkan bahwa hasil belajar siswa siklus II sudah meningkat, karena itu diputuskan untuk tidak melanjutkan penelitian pada siklus berikutnya. Dengan demikian penelitian ini telah selesai

PTK ini terdiri dari dua siklus, yang mana setiap siklus terdiri dari dua kali pertemuan dan satu kai tes hasil belajar pada setiap akhir siklus. Pelaksanaan pembelajaran dilaksanakan dengan menggunakan Tipe Pembelajaran Pair Checks. Peneliti ini menggunakan instrumen penelitian berupa lembar observasi aktivitas guru, tes hasil belajar sisiwa berupa ujian akhir siklus dan kamera.

\section{Hasil Pengamatan kegiatan Guru dalam pelaksanaan pembelajaran}

Peresentase rata-rata kegiatan guru dalam proses pelaksanaan terjadi peningkatan melalui Tipe Pembelajaran Pair Checks. Hal ini dapat dilihat pada tabel 11 dibawah ini:

Tabel 11. Presentase Aktivitas Guru Kelas VI Pada Pembelajaran PKn melalui Tipe Pembelajaran Pair Checks di UPT SDN 20 Koto Langang Kec. Ranah Pesisir Pesisir Selatan pada siklus I dan II

\begin{tabular}{llccc}
\hline No & Pertmuan & $\begin{array}{c}\text { Presentase } \\
(\%) \text { siklus I }\end{array}$ & $\begin{array}{c}\text { Presentase (\%) } \\
\text { siklus II }\end{array}$ & Keterangan \\
\hline $\mathbf{1}$ & I & $70 \%$ & $80 \%$ & Mengalami peningkatan 10\% \\
\hline $\mathbf{2}$ & II & $75 \%$ & $85 \%$ & Mengalami peningkatan $10 \%$ \\
\hline & $\begin{array}{l}\text { Rata-rata } \\
\text { Presentase }\end{array}$ & $72,5 \%$ & $82,5 \%$ & Mengalami peningkatan $10,0 \%$ \\
\hline
\end{tabular}

Berdasarkan Tabel di atas, diketahi bahwa pelaksanaan pembelajaran Pkn siswa kelas VI dengan menggunakan Tipe Pembelajaran Pair Checks pada aspek kegiatan guru, pada siklus I diperoleh resentase ratarata $72,5 \%$ dapat dikatakan cukup baik pada siklus II, rara-rata kegiatan guru mencapai presentase $82,5 \%$ dapat dikatakan baik, sehingga pelaksanaan pembelajaran Pkn mengalami peningkatan dari siklus I dan siklus II adalah:

\section{Hasil Belajar Ranah Afektif}

Keberhasilan belajar siswa dalam pembelajaran pada umumnya dilihat sari hasil belajar ranah kognitif yang tinggi, namun proses pelaksanaanya pembelajaran juga memegang peranan dalam meningkatkan hasil belajar siswa dalam mengikuti proses pembelajaran berlangsung, sehingga dengan meningkatnya partisipasi siwa pembelajaran PKn, diharapkan hasil belajar PKn siswa juga meningkat.

Disimpulkan bahwa pembelajaran dengan menggunkan tipe pembelajaran Pair Checks, terjadi peningkatan aspek afektif tanggung jawab siswa. Hal ini terbukti dari kenaikan rata-rata untuk masing-masing indikator keberhasilan aspek afektif siswa yang sudah di tentukan. Aspek tanggung jawab siswa pada siklus I aspek tanggung jawab siswa dengan rata-rata 67,62 di kategorikan cukup baik. Tetapi belum mencapai kriteria ketuntasan. Pada siklus II aspek tanggung jawab siswa dengan rata-rata 85,00 dengan ini sudah di kategorikan baik. Sehingga aspek tanggung jawab siswa dengan menggunakan tipe pembelajaran Pair Checks mengalami peningkatan 17,38 dari siklus I ke siklus II. 


\section{Hasil Belajar Ranah Kognitif Siswa}

Pencapaian hasil belajar siswa diperoleh melalui tes hasil belajar di akhir siklus. Tentang hasil belajar siswa pada siklus I, siswa yang tuntas belajar ada 7 orang $(66,66 \%)$ dan yang belum tuntas belajar ada 5 orang $(34,34 \%)$ dengan nilai rata-rata 57,75 . Sedangkan pada siklus II, siswa yang tuntas belajar ada 10 orang (83\%) dan yang belum tuntas belajar hanya 2 orang $(16,66 \%)$ dengan rata-rata 78,25 . Dengan demikian dapat di Buat kesimpulan bahwa presentase ketuntasan belajar siswa dari siklus I ke siklus II mengalami peningkatan sebesar $12 \%$ dan nilai rata-rata hasil belajar sudah mencapai standar KKM yaitu 75 .

\section{Uji Hipotesis}

Dari hasil analisis data dan pembahasan tentang Tipe Pembelajaran Pair Checks dapat di simpulkan bahwa terjadi peningkatan hasil belajar siswa pada pembelajaran PKn kelas VI di UPT SDN 20 Koto Langang Kec. Ranah Pesisir Kabupaten Pesisir Selatan. Dari lembar hasil belajar siswa terlihat peningkatan rata-rata ketuntasan hasil belajar ranah kognitif siswa pada siklus I sebesar $60 \%$ Sedangkan pada siklus II rata-rata ketuntasan belajar ranah kognitif siswa sebesar $80 \%$ jadi, presentase peningkatan hasil belajar ranah kognitif siswa yang mencapai ketuntasan belajar mengalami peningkatan $12 \%$.

Dengan demikian, hipotesis tindakan pada penelitian ini bahwa hasil belajar siswa dalam pembelajaran PKn kelas VI UPT SDN 20 Koto Langang Kec. Ranah Pesisir Pesisir Selatan dapat di tingkatkan melalui Tipe Pembelajaran Pair Checks. Dengan di terimanya hipotesis penelitian ini, maka PTK tentang pembelajaran PKn dengan menggunkan Tipe Pembelajaran Pair Checks yang peneliti lakukan dapat di akhiri.

\section{Kelemahan Penelitian dan Rekomendasi}

Berdasarkan gambaran dan penjelasan yang di mulai dari hasil penelitian dan pembahasan, dapat disimpulkan bahwa penelitian tindakan kelas dengan judul "Peningkatan Hasil Belajar Siswa Kelas VI Pada Pembelajaran Pkn Melalui Tipe Pembelajaran Pair Checks Di UPT SDN 20 Koto Langang Kec. Ranah Pesisir Pesisir Selatan" sudah bisa dikatakan berhasil. Hal ini terjadi karena peningkatan di lihat dari tanggung jawab, pelaksanaan guru dan hasil belajar siswa.

Dari hasil diskusi dengan observer setelah siklus II dilaksanakan, penelitian menyimpulkan bahwa Tipe Pembelajaran Pair Checks dapat membuat suasana belajar lebih bermakna dan menyenangkan bagi siswa. Akan tetapi ada kelemhan yang peneliti hadapi saat pelaksanaan pembelajaran yaitu:

1. Pada pembelajaran dengan menggunkan Tipe pembelajaran Pair Checks siswa meribut saat membuat dan menjawab pertanyaan, akan tetapi semua bisa diatasi oleh guru, guru harus mampu untuk mengkondisikan kelas.

2. Waktu yang sangat dibatasi sehingga aktifitas siswa dalam berdiskusi kurang maksimal. Akan tetapi, seorang guru harus mampu membagi waktu dengan baik agar proses pembelajaran dapat berjalan dengan yang diharapkan.

Dengan peningkatan hasil belajar siswa di atas dengan menggunakan Tipe pembelajaran Pair Checks disarankan kepada guru dan peneliti lainya untuk menggunakan Tipe pembelajaran Pair Checks sebagai salah satu alternatif peningkatan hasil belajar siswa dalam pembelajaran Pkn.

\section{Simpulan}

Berdasarkan hasil penelitian dan pembahasan, dapat disimpulkan sebagai berikut: 1) Peningkatan persentase ketuntasan hasil belajar ranah kognitif (aspek pemahaman) siswa dari siklus I sebesar $60 \%$ dengan nilai ratarata 57,75 meningkat pada siklus II menjadi $80 \%$ dengan nilai rata-rata 79,$25 ; 2$ ) Peningkatan rata-rata ranah afektif (aspek tanggung jawab) siswa adalah 67,62 pada siklus I dan meningkat pada siklus II menjadi 85,00; 3) Hal ini berarti bahwa pelaksanaan pembelajaran PKn melalui Tipe Pembelajaran Pair Checks pada kelas VI di UPT SDN 20 Koto Langang Kec. Ranah Pesisir Pesisir Selatan berlangsung dengan baik dalam hal meningkatkan Hasil belajar siswa.

\section{Referensi}

Anitah Sri, dkk. (2008). Strategi Pembelajaran di SD. Jakarta: Universitas Terbuka.

Arikunto, Suharsimi, dkk.(2012). Penelitian Tindakan Kelas. Jakarta: Bumi Aksara

Desfitri, Rita, dkk. (2008). "Peningkatan Aktivitas, Motivasi, dan Hasil Belajar Matematika Siswa Kelas VIII2 MTsN Model Padang melalui Pendekatan Kontekstual". Laporan Pengembangan Inovasi Pembelajaran di sekolah (PIPS). Padang: FKIP Universitas Bung Hatta

Dimyanti dan Mudjianto. (2010). Belajar dan Pembelajaran. Jakarta: Rineka Cipta 
Fitri, Yani. (2015)."Penerapan Tipe Pair Checks Untuk Meningkatkan Aktivitas Dan Hasil Belajar Siswa" Skripsi:Universitas Lampung.

Huda. (2014). Model-Model Pengajaran Dan Pembelajaran. Yogyakarta: Cileban Timur

Istarani dan Ridwan (2015). 50 Tipe Strategi dan Teknik Pembelajaran Koopratif. Medan: Media Persada.

Kurikulum Tingkat Satuan Pendidikan (KTSP). Jakarta: Dirjen Pedidikan Tinggi.

Reni, Utami. (2014)."Pair Checks Untuk Meningkatkan Aktivitas dan Hasil Belajar" Skripsi: Universitas Lampung.

Ruminiati, (2007).Pengembangan Pendidikan Kewarganegaraan SD. Jakarta: Dirjen Pendidikan Tinggi.

Sudjana, Nana. (2012). Peilaian Hasil Proses Belajar Mengajar. Bandung: Remaja Rosdakarya.

Susanto, Ahmad. (2014). Teori Belajar dan Pembelajaran di SD. Jakarta: Kencana Prenadamedia Group.

Suprihatiningrum, Jamil. (2013). Strategi Pembelajaran. Yogyakarta: AR-Ruzz Media

Wardani, I.G.A.Kdkk. (2010).Penelitian Tindakan Kelas. Jakarta: Universitas Terbuka.

Winataputra, dkk. (2007). Materi dan Pembelajaran PKn SD. Jakarta: Universitas Terbuka. 